\title{
Risk factors for adenocarcinoma in the surgically transposed colon not exposed to the fecal stream. Etiological considerations extrapolated to sporadic colon carcinoma in the general population
}

\author{
Antonio V. Sterpetti ${ }^{*}$, Luca Di Marzo, Paolo Sapienza \\ Department of Surgery, Univesity of Rome, Sapienza, Italy
}

\section{A R T I C L E I N F O}

\section{Article history:}

Accepted 22 October 2020

Available online $\mathrm{xxx}$

\section{Keywords:}

Etiology of colon cancer

Sporadic colom cancer

Inflammation and cancer

\begin{abstract}
A B S T R A C T
Background: The aim of the study was to analyze the clinical characteristics and outcomes of patients with de novo secondary adenocarcinoma arising in the operatively transposed colon not exposed to the fecal stream.

Methods: Two investigators collected and reviewed papers from June 1938 to June 2019, reporting patients with adenocarcinoma arising in the transposed colon, not in contact with the fecal stream.

Results: Overall, we identified 98 patients with a transposed colonic autograft, positioned as conduit but not in contact with the fecal stream, in whom a secondary de novo adenocarcinoma was diagnosed. In $50 \%$ of the patients, the secondary adenocarcinoma was diagnosed at an advanced stage, with a subsequent poor clinical outcome. Earlier diagnosis allowed local resection with long term success. The occurrence of the adenocarcinoma appeared to be closely related to aging, and to clinical evidence of chronic inflammation.

Conclusions: Patients in whom the colon has been surgically transposed to different anatomic positions, away from the fecal stream, can develop a secondary colonic adenocarcinoma with. Aging and chronic inflammation seem to be risk factors for a secondary adenocarcinoma more than time from implant. Screening for polyps and adenocarcinomas in these patients should be considered.
\end{abstract}

(๑) 2020 Elsevier Ltd, BASO The Association for Cancer Surgery, and the European Society of Surgical Oncology. All rights reserved.

\section{Introduction}

Adenocarcinoma arising in the surgically transposed colon, not in contact with the fecal stream, has been considered a rare complication. We performed a systematic review to analyze the reports of de novo, secondary adenocarcinomas arising in the surgically transposed colon, not in contact with the fecal stream. The primary outcome of this systematic review was to analyze the prevalence and risk factors for this complication. Patients who had ureterosigmoidostomy, were excluded from the analysis; the significant high prevalence of adenocarcinoma in the colon exposed simultaneously to urine and feces is well known, reaching a 30-100 fold increase in comparison to the general population, adjusted for age and sex [1].

A close correlation between sporadic colon cancer prevalence

\footnotetext{
* Corresponding author.

E-mail address: antonio.sterpetti@uniroma1.it (A.V. Sterpetti).
}

and several characteristics of western life style, like high intake of red and processed meat, obesity, alcohol abuse, cigarette smoking is evident in epidemiologic studies [2,3]. The analysis of patients who develop adenocarcinoma in the colon not exposed to the fecal stream, allows to look at the etiology of sporadic colon cancer by an alternative point of view. The colon is transposed in different physiological conditions from its natural environment, and the usual potential risk factors, traditionally considered as causal agents, are not present [3].

\section{Methods}

The methods used for the study and inclusion criteria were based on Preferred Reports Items for Systematic Reviews and Meta analyses recommendations. There was no language or time restriction. We were able to identify 90 papers reporting 98 patients with a secondary adenocarcinoma arising in the surgically transposed colon autograft, not in contact with the fecal stream for more than 1 year, complete information was available in 86 patients (Suppl 1). 


\section{Results}

\section{Colon transplant for vaginal reconstruction}

Eight patients developed secondary adenocarcinoma in the colon used as neovagina. All patients had general (fever) and local signs of chronic inflammation (discharge and bleeding). The tumor was a mucinous adenocarcinoma (Table 1 ).

\section{Colon transplant after esophagectomy and/or gastrectomy}

In forty patients a diagnosis of de novo adenocarcinoma in the transposed colon was made. Patients consumed red meat only occasionally and no one was obese. Two patients were smokers and two alcoholic. Ten patients had systemic signs of inflammation (fever) (Table 2).

Colon as urinary conduit or colocystoplasty not exposed to the fecal stream

All 38 patients in whom information was complete complained of general and local signs of chronic inflammation (fever, local pain) (Table 3).

There was no difference between the characteristics of secondary adenocarcinoma in patients originally operated upon for benign or malignant disease. In patients operated upon for benign disease, the adenocarcinoma occurred after a longer implantation time in comparison with patients originally operated upon for malignant disease $(p<0.001)$ (Table 4$)$. The occurrence of the secondary adenocarcinoma appeared correlated more with the age of the patients that with the time from implant. The recognized risk factors for sporadic colon cancer (alcohol abuse, smoking, red meat intake, obesity) were not present. The presence of local and general sings of chronic inflammation represented a significant risk factors for earlier development of the tumor.

\section{Discussion}

Colorectal cancer incidence rates vary widely by world region. High intake of sugars and processed meat, alcohol drinks, and body fatness increase the risk for sporadic colon cancer, whereas physical activity is protective [1-6] Epidemiological analyses have shown a decreasing incidence of colon cancer in USA and some western European countries. This trend started well before the implementation of screening programs, almost independently by new therapies. The decreased incidence has been registered for patient older than 60 years, who represent most of the patients with colon cancer. There has been an increasing incidence and mortality for patients younger than 50 years in USA and western European countries [7-9]. In our analysis we found similarities between the secondary adenocarcinoma, arising in the colonic wall not exposed to the fecal stream, and sporadic colon cancer in the general population. The clinical conditions of the patients, and the new position of the colon, did not allow the action of several factors, generally considered as major risk for colon cancer occurrence. The new location of the transposed colon, prevents the action of toxins, derived from degradation of ingested substances, like red meat and sugars. No one of the reported patients was obese, and only few abused of alcohol and tobacco. The colonic wall was exposed to different bacterial flora. Conceptually the risk factors identified for sporadic colon cancer in the general population and in the surgically transposed colon have in common the possibility to promote inflammation either locally or systematically [4,5,10,11].

Table 1

Stage of de novo secondary adenocarcinoma - colon as neovagina (8 patients).

\begin{tabular}{|c|c|c|c|c|c|c|c|c|}
\hline & $\begin{array}{l}\text { MEAN AGE } \\
\text {-YEARS } \\
\text { (RANGE) }\end{array}$ & $\begin{array}{l}\mathrm{M} / \\
\mathrm{F}\end{array}$ & $\begin{array}{l}\text { INDICATION TO } \\
\text { INITIAL SURGERY } \\
\text { BENIGN/MALIGNANT }\end{array}$ & $\begin{array}{l}\text { MEAN TIME FROM } \\
\text { INITIAL SURGERY TO } \\
\text { DIAGNOSIS (YEARS) }\end{array}$ & $\begin{array}{l}\text { ENDOSCOPIC } \\
\text { RESECTION }\end{array}$ & $\begin{array}{l}\text { SURGICAL } \\
\text { RESECTION }\end{array}$ & $\begin{array}{l}\text { SUPPORTIVE } \\
\text { THERAPY }\end{array}$ & AVAILABLE FOLLOW-UP \\
\hline \multicolumn{9}{|c|}{$\begin{array}{l}\text { ADENOCARCINOMA ( } 8 \text { Patients) } \\
\text { LOCALIZED DISEASE } 0 / 8\end{array}$} \\
\hline $\begin{array}{l}\text { LOCALLY } \\
\text { ADVANCED } \\
\text { DISEASE } 7 / 8 \\
(87.5 \%))\end{array}$ & $\begin{array}{l}57.1(43 \\
-73)\end{array}$ & $\begin{array}{l}0 / \\
7\end{array}$ & $4 / 3$ & $29.7(3-53)$ & 0 & 7 & 0 & $\begin{array}{l}\text { Alive without disease } 6 / 7 \text { (mean follow-up } 12 \\
\text { months); } 1 \text { patient died at } 16 \text { months with } \\
\text { diffuse liver metastases }\end{array}$ \\
\hline $\begin{array}{l}\text { METASTATIC } \\
\text { DISEASE } 1 / 8 \\
(12.5 \%)\end{array}$ & 33 & $\begin{array}{l}0 / \\
1\end{array}$ & $1 / 0$ & 20 & 0 & 0 & 1 & No available follow-up \\
\hline
\end{tabular}

Table 2

Stage of the de novo secondary adenocarcinoma -colon interpositon after esophagectomy and/or gastrectomy ( 40 patients with complete information out of 43 patients).

\begin{tabular}{|c|c|c|c|c|c|c|c|c|}
\hline STAGE DISEASE & $\begin{array}{l}\text { AGE } \\
\text { (RANGE) }\end{array}$ & $\begin{array}{l}\mathrm{M} / \\
\mathrm{F}\end{array}$ & $\begin{array}{l}\text { INDICATION TO INITIAL } \\
\text { SURGERY. BENIGN/ } \\
\text { MALIGNANT }\end{array}$ & $\begin{array}{l}\text { TIME FROM INITIAL } \\
\text { SURGERY AND DIAGNOSIS } \\
\text { YEARS (RANGE) }\end{array}$ & $\begin{array}{l}\text { ENDOSCOPIC } \\
\text { RESECTION }\end{array}$ & $\begin{array}{l}\text { SURGICAL } \\
\text { RESECTION }\end{array}$ & $\begin{array}{l}\text { SUPPORTIVE } \\
\text { THERAPY }\end{array}$ & AVAILABLE FOLLOW-UP \\
\hline $\begin{array}{l}\text { LOCALIZED } \\
\text { DSEASE } \\
21 / 40(52.5 \%)\end{array}$ & $\begin{array}{l}64.5(40 \\
-80)\end{array}$ & $\begin{array}{l}12 / \\
9\end{array}$ & $9 / 12$ & $21(1-55)$ & 6 & 15 & 0 & $\begin{array}{l}\text { Alive without disease } 21 / 21 \text { (Mean } \\
\text { follow-up } 17 \text { months-range } 1-108 \\
\text { months) }\end{array}$ \\
\hline $\begin{array}{l}\text { LOCALLY } \\
\text { ADVANCED } \\
\text { DISEASE 5/ } \\
40(12.5 \%)\end{array}$ & $\begin{array}{l}65,2(53 \\
-83)\end{array}$ & $3 / 1$ & $2 / 3$ & $22(12-42)$ & 0 & 5 & 0 & $\begin{array}{l}1 \text { pt Alive with disease at } 24 \text { months. } \\
1 \text { pt alive and well at } 6 \text { months } \\
\text { Death from disease } 3 \text { pts (Mean } \\
\text { follow-up } 17 \text { months- range } 9 \\
-24 \text { months). }\end{array}$ \\
\hline $\begin{array}{l}\text { METASTATIC } \\
\text { DISEASE } \\
14 / 40(35 \%)\end{array}$ & $\begin{array}{l}66.8(41 \\
-83)\end{array}$ & $8 / 6$ & $7 / 6$ (1 unspecified $)$ & $20(8-47)$ & 0 & 1 & 13 & $\begin{array}{l}\text { All died from disease within } 12 \\
\text { months (mean } 4 \text { months). }\end{array}$ \\
\hline
\end{tabular}


Table 3

Stage of de novo secondary adenocarcinoma- urinary colon conduit not exposed to fecal stream (38 patients with complete information out 47 patients).

\begin{tabular}{|c|c|c|c|c|c|c|c|c|}
\hline $\begin{array}{l}\text { STAGE } \\
\text { DISEASE }\end{array}$ & $\begin{array}{l}\text { MEAN } \\
\text { AGE } \\
\text {-YEARS } \\
\text { (RANGE) }\end{array}$ & $\begin{array}{l}\mathrm{M} / \\
\mathrm{F}\end{array}$ & $\begin{array}{l}\text { INDICATION TO } \\
\text { INITIAL SURGERY } \\
\text { BENIGN/ } \\
\text { MALIGNANT }\end{array}$ & $\begin{array}{l}\text { MEAN TIME FROM } \\
\text { INITIAL SURGERY TO } \\
\text { DIAGNOSIS (YEARS) }\end{array}$ & $\begin{array}{l}\text { ENDOSCOPIC } \\
\text { RESECTION }\end{array}$ & $\begin{array}{l}\text { SURGICAL } \\
\text { RESECTION }\end{array}$ & $\begin{array}{l}\text { SUPPORTIVE } \\
\text { THERAPY }\end{array}$ & AVAILABLE FOLLOW-UP \\
\hline $\begin{array}{l}\text { LOCALIZED } \\
\text { DISEASE } 13 / \\
38(34 \%)\end{array}$ & $\begin{array}{l}67.4(42 \\
-82)\end{array}$ & $\begin{array}{l}8 / \\
5\end{array}$ & $3 / 10$ & $13.0(2-29)$ & 3 & 10 & 0 & $\begin{array}{l}\text { Alive without disease } 12 / 13 \text { (mean follow-up } 20 \\
\text { months); } 1 \text { patient died } 3 \text { months after resection from } \\
\text { small bowel fistula }\end{array}$ \\
\hline $\begin{array}{l}\text { LOCALLY } \\
\text { ADVANCED } \\
\text { DISEASE } 13 / \\
38(34 \%))\end{array}$ & $\begin{array}{l}53.7(29 \\
-80)\end{array}$ & $\begin{array}{l}7 / \\
6\end{array}$ & $8 / 5$ & $19.5(8-40)$ & 0 & 13 & 0 & $\begin{array}{l}\text { Alive without disease } 12 / 13 \text { (mean follow-up } \\
7 \text { months); } \\
1 \text { patient died at } 48 \text { months from diffuse metastases }\end{array}$ \\
\hline $\begin{array}{l}\text { METASTATIC } \\
\text { DISEASE } 12 / \\
38(32 \%)\end{array}$ & $\begin{array}{l}61.2(47 \\
-80)\end{array}$ & $\begin{array}{l}7 / \\
5\end{array}$ & $2 / 10$ & $10.3(3-21)$ & 0 & 6 & 6 & $\begin{array}{l}\text { Six patients who had only supportive therapy died } \\
\text { within } 6 \text { months. } \\
\text { Of the } 6 \text { patients who had resection, } 3 \text { died within } 3 \\
\text { months, and } 1 \text { died at } 17 \text { months. Two patients are } \\
\text { alive respectively at } 1 \text { and } 18 \text { months from surgery }\end{array}$ \\
\hline
\end{tabular}

Table 4

Age of patients at the time of the diagnosis of De novo adenocarcinoma and time interval from initial surgery TIME INTERVAL BETWEEN INITIAL SURGERY AND DIAGNOSIS OF DE NOVO ADENOCRACINOMA NEOVAGINA (8)

(

$\begin{array}{ll}\text { POST- } & \text { COLON URINARY } \\ \text { ESOPHAGECTOMY } & \text { CONDUIT NOT } \\ \text { AND/OR } & \text { EXPOSED TO FECAL }\end{array}$
GASTRECTOMY (40) STREAM (38)

\begin{tabular}{|c|c|c|c|c|c|c|c|c|}
\hline $1-10$ years & & \multicolumn{3}{|l|}{1} & \multicolumn{2}{|l|}{12} & \multicolumn{2}{|l|}{15} \\
\hline $11-20$ years & & \multicolumn{2}{|l|}{2} & & \multicolumn{2}{|l|}{13} & \multicolumn{2}{|l|}{14} \\
\hline $21-30$ years & & \multicolumn{2}{|l|}{2} & & \multicolumn{2}{|l|}{4} & \multicolumn{2}{|l|}{7} \\
\hline More than 30 years & & \multicolumn{2}{|l|}{3} & & \multicolumn{2}{|l|}{11} & \multicolumn{2}{|l|}{2} \\
\hline Mean Interval (years) & & \multicolumn{2}{|l|}{28.6} & & \multicolumn{2}{|l|}{20.7} & \multicolumn{2}{|l|}{15.1} \\
\hline TIME INTERVAL AND INDICATION TO INITIAL SURGERY & & \multicolumn{2}{|c|}{ MALIGNANT } & BENIGN & MALIGNANT & BENIGN & MALIGNANT & BENIGN \\
\hline $1-10$ years & & \multicolumn{2}{|l|}{1} & & 9 & 3 & 14 & 1 \\
\hline $11-20$ years & & \multicolumn{2}{|l|}{1} & 1 & 4 & 9 & 8 & 6 \\
\hline $21-30$ years & & \multicolumn{2}{|l|}{1} & 1 & 2 & 2 & 1 & 6 \\
\hline More than 30 years & & \multirow{2}{*}{\multicolumn{2}{|c|}{14.3}} & 3 & & 11 & & 2 \\
\hline Mean Interval (years) & & & & 37.2 & 9.2 & 27.2 & 9.8 & 23.2 \\
\hline AGE AT THE TIME DIAGNOSIS OF DE NOVO ADENOCARCINOMA & TOTAL (86) & \multicolumn{3}{|l|}{ NEOVAGINA 8} & \multicolumn{2}{|c|}{$\begin{array}{l}\text { POST- } \\
\text { ESOPHAGECTOMY } \\
\text { AND/OR } \\
\text { GASTRECTOMY (40) }\end{array}$} & \multicolumn{2}{|c|}{$\begin{array}{l}\text { COLON URINARY } \\
\text { CONDUIT NOT } \\
\text { EXPOSED TO FECAL } \\
\text { STREAM (38) }\end{array}$} \\
\hline$<35$ & 2 & \multicolumn{3}{|l|}{1} & \multicolumn{2}{|c|}{0} & \multicolumn{2}{|l|}{1} \\
\hline $36-45$ & 8 & \multicolumn{3}{|l|}{1} & \multicolumn{2}{|c|}{2} & \multicolumn{2}{|l|}{5} \\
\hline $46-55$ & 11 & \multicolumn{3}{|l|}{2} & \multicolumn{2}{|c|}{5} & \multicolumn{2}{|l|}{4} \\
\hline $56-65$ & 20 & \multicolumn{3}{|l|}{2} & 1 & & 7 & \\
\hline $66-75$ & 30 & 2 & & 1 & 6 & & 12 & \\
\hline$>75$ & 15 & 0 & & 6 & & & 9 & \\
\hline Mean Age (years) (range) & $62.2(29-83)$ & $54.1(33-73)$ & & & $5.0(40-83)$ & & $60.8(29-82)$ & \\
\hline Indication initial surgery & & & & & & & & \\
\hline Benign & 57.7 & Benign & 57.4 & & enign & 61.3 & Benign & 51.4 \\
\hline Malignant & 67.2 & Malignant & 48.7 & & Malignant & 60.6 & Malignant & 68.8 \\
\hline
\end{tabular}

\section{Conclusions}

Inflammation may act as cancer promoter either at a local or at a systemic level [11,12]. The systemic action of chronic inflammation may explain the almost simultaneous occurrence of colon cancer in two different anatomic positions. We might hypothesize that the reduced incidence and mortality for colon cancer in USA and some western European countries might be related to the diffuse prescription of Aspirin, for its anti-platelet action, and Statins, for their hypocholesterolemic effect for people older than 60 of age to prevent cardiovascular events. Both drugs have also a generic antiinflammatory action. A reduced risk for colorectal cancer has been reported in patients taking aspirin and statin use, with an up to $90 \%$ risk reduction in inflammatory bowel disease-related colorectal cancer [6]. This hypothesis might also explain the simultaneous increased prevalence of colon cancer for people younger than 45 years, to whom rarely aspirin and statins are prescribed to prevent cardiovascular events.

\section{Fundings}

No fund was received for this work.

\section{Declaration of competing interest}

The authors have no conflcits of interest to disclose.

Data are available on request and described in the supplement. 


\section{Appendix A. Supplementary data}

Supplementary data to this article can be found online at https://doi.org/10.1016/j.ejso.2020.10.026.

\section{References}

[1] Araghi M, Soerjomataram I, Bardot A, et al. Changes in colorectal cancer incidence in seven high-income countries: a population-based study. Lancet Gastroenterol Hepatol 2019 Jul;4(7):511-8. https://doi.org/10.1016/S24681253(19)30147-5.

[2] Siegel RL, Fedewa SA, Anderson WF, et al. Colorectal cancer incidence patterns in the United States, 1974-2013. J Natl Cancer Inst 2017;109. https://doi.org/ 10.1093/jnci/djw322. August 1.

[3] Bray F, Ferlay J, Soerjomataram I, Siegel RL, Torre LA, Jemal A. Global cancer statistics 2018: GLOBOCAN estimates of incidence and mortality worldwide for 36 cancers in 185 countries. Ca - Cancer J Clin 2018;68:394-424. https:// doi.org/10.3322/caac. 2149.

[4] Siegel RL, Torre LA, Soerjomataram I, Hayes RB, Bray F, Weber TK, et al. Global patterns and trends in colorectal cancer incidence in young adults. Gut 2019 Dec;68:2179-85. https://doi.org/10.1136/gutjnl-2019-319511.

[5] Stephensen BD, Reid F, Shaikh S, Carroll R, Smith SR, Pockney P, on behalf of the PREDICT Study Group collaborators. C-reactive protein trajectory to predict colorectal anastomotic leak: Predict Study. Br J Surg 2020 Jul 16. https:// doi.org/10.1002/bjs.11812 [Online ahead of print]
[6] Cullinane CM, Creavin B, O'Connell EP, Kelly L, O'Sullivan MJ, Corrigan MA, et al. Risk of colorectal cancer associated with BRCA1 and/or BRCA2 mutation carriers: systematic review and meta-analysis. Br J Surg 2020 Jul;107(8): 951-9. https://doi.org/10.1002/bjs.11603. Epub 2020 Apr 16.

[7] Denost Q. The challenge posed by young-onset rectal cancer. Br J Surg 2020 Apr;107(5):481-3. https://doi.org/10.1002/bjs.11591.

[8] Zaborowski AM, Murphy B, Creavin B, Rogers AC, Kennelly R, Hanly A, et al. Clinicopathological features and oncological outcomes of patients with youngonset rectal cancer. Br J Surg 2020 Apr;107(5):606-12. https://doi.org/ 10.1002 /bjs.11526.

[9] Chambers AC, Dixon SW, White P, Williams AC, Thomas MG, Messenger DE. Demographic trends in the incidence of young-onset colorectal cancer: a population-based study. Br J Surg 2020 Apr;107(5):595-605. https://doi.org/ 10.1002 /bjs. 11486

[10] Sterpetti AV. Sapienza P Adenocarcinoma in the transposed colon. High grade active inflammation versus low grade chronic inflammation. Eur J Surg Oncol 2019;5:1536-41. https://doi.org/10.1016/j.ejso.2019.05.012.

[11] Samadder NJ, Mukherjee B, Huang SC, et al. Risk of colorectal cancer in selfreported inflammatory bowel disease and modification of risk by statin and NSAID use. Cancer 2011;117(8):1640-8. https://doi.org/10.1002/cncr.25731.

[12] Sterpetti AV, Sapienza P, Fiori E, Marzo LD, Lamazza A. Improved results for left-sided malignant colorectal obstruction with a proper selection for self expandable metal stent placement, surgical resection or diverting stoma. Eur J Surg Oncol 2020 Jul 17;S0748-7983(20). https://doi.org/10.1016/ j.ejso.2020.07.020. 30647-8. 